\title{
Tomasz Siudek
}

Katedra Ekonomiki i Organizacji Przedsiębiorstw

Szkoła Główna Gospodarstwa Wiejskiego w Warszawie

\section{Dług publiczny jako zagrożenie dla wzrostu gospodarczego krajów na świecie}

\section{Streszczenie}

Głównym celem pracy jest określenie związku między poziomem wzrostu gospodarczego a poziomem długu publicznego w wybranych krajach na świecie. Dodatkowym celem badań jest ustalenie poziomu i determinant długu publicznego w badanych krajach. Z uzyskanych danych wynika, że wzrost długu publicznego powoduje spadek poziomu wzrostu gospodarczego w większości badanych krajów na świecie.

Słowa kluczowe: dług publiczny, determinanty długu publicznego, koszty obsługi długu publicznego, wzrost gospodarczy.

\section{Wprowadzenie}

Dług publiczny ma wiele definicji. Według $\mathrm{OECD}^{1}$ określany jest on jako zobowiązania finansowe wszystkich jednostek sektora instytucji rządowych

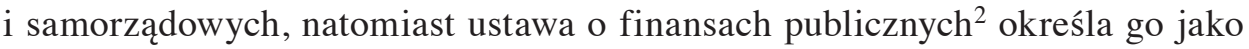
zobowiązanie sektora finansów publicznych z tytułu: wyemitowanych papierów wartościowych opiewających na wierzytelności, zaciągniętych kredytów i pożyczek, przyjętych depozytów czy też wymagalnych zobowiązań wynikających

\footnotetext{
${ }^{1}$ http://stats.oecd.org/, dostęp: 10.01.2014.

${ }^{2}$ Ustawa z dnia 27 sierpnia 2009 r. o finansach publicznych, Dz.U. nr 157, poz. 1240.
} 
z odrębnych ustaw oraz prawomocnych orzeczeń sądów lub ostatecznych decyzji administracyjnych.

Przyczynami długu publicznego mogą być [Barro 1979, Roubini i Sachs 1989, Jeanne i Guscina 2006, Reinhart i Rogoff 2010]:

- deficyt budżetowy utrzymujący się przez wiele lat,

- wysokie wydatki publiczne, zwłaszcza w okresach wojen i głębokich kryzysów gospodarczych,

- nieprzewidywalne, losowe sytuacje, np. klęski żywiołowe,

- realizowana doktryna publiczna, która zakłada świadome utrzymywanie deficytu budżetowego i długu publicznego jako narzędzi interwencjonizmu państwowego,

- osiągnięcie celów politycznych władzy, która nie decyduje się na podnoszenie podatków i nie dokonuje również redukcji wydatków publicznych,

- starzenie się społeczeństwa, czego efektem jest wzrost wydatków społecznych.

Dług publiczny to jeden z głównych problemów polityki gospodarczej. Stanowi on jeden z ważniejszych obszarów finansów publicznych. Ma on ogromny wpływ na stan finansów państwa i rozwój gospodarczy. Ze względu na ostatni kryzys finansowy na świecie wzrosło zainteresowanie problematyką długu publicznego, zarówno ze strony ekonomistów, instytucji finansowych, jak i władz publicznych. Dług publiczny jest dużym zagrożeniem prawidłowego rozwoju gospodarczego krajów na świecie. Skutkiem jego wysokiej wartości są często duże problemy finansowe i społeczne.

\section{Cel, zakres i metody badań}

Głównym celem badań było określenie wpływu długu publicznego na wzrost gospodarczy w wybranych krajach na świecie. Dodatkowym celem badań było ustalenie poziomu i determinant długu publicznego w badanych krajach. W pracy sformułowano hipotezę badawczą, zgodnie z którą wzrost długu publicznego powoduje spadek poziomu wzrostu gospodarczego krajów na świecie. Praca składa się z części teoretycznej i empirycznej. W części teoretycznej ukazano pojęcia, klasyfikację i przyczyny długu publicznego, a w części empirycznej poziom i determinanty długu publicznego oraz wpływ długu na wzrost gospodarczy wybranych krajów na świecie.

Część teoretyczną pracy opracowano na podstawie studium literatury przedmiotu, a część empiryczną oparto na danych pozyskanych z bazy Eurostat i Banku Światowego. W celu określenia determinant długu publicznego w Polsce, Grecji i USA zastosowano analizę regresji krokowej wstecz, w której wykorzystano 25 zmiennych makroekonomicznych. Stopień dopasowania modelu do danych empirycznych wyrażono współczynnikiem determinacji $R^{2}$, natomiast stopień 
autokorelacji reszt zbadano testem Durbina-Watsona. Przyjęto, że wartości $D W<1,4$ oznaczają istotne korelacje pomiędzy resztami [Dobosz 2001]. Związek między wzrostem gospodarczym a poziomem długu publicznego w wybranych krajach na świecie zbadano z wykorzystaniem współczynników korelacji Pearsona i współczynników regresji. Ich istotność określono testem $t$-Studenta.

Poziom długu publicznego w całej Unii Europejskiej analizowano w latach 2000-2012, a w poszczególnych krajach UE tylko w 2012 r. Dług publiczny w Polsce badano w latach 2000-2012. Analiza wpływu długu publicznego na wzrost gospodarczy w wybranych krajach na świecie obejmowała lata 1995-2012.

\section{Badania długu publicznego - przegląd literatury}

Dług publiczny jest szeroko omawiany w literaturze. Na szczególną uwagę zasługują profesorowie C.M. Reinhart i K. Rogoff, których dorobek naukowy należy do największych z tego zakresu. Głównym przedmiotem ich badań jest historia długu publicznego. Badacze ci stwierdzili, że największy odsetek niewypłacalnych krajów na świecie (ponad 20\%) wystąpił w latach 1830-1860, 1870-1880, 1930-1950 i 1980-1995. Według nich odsetek ten wzrasta wraz ze wzrostem udziału długu publicznego w PKB tych krajów [Reinhart i Rogoff 2008].

W literaturze dominują dwa kierunki badań długu publicznego. Pierwszy koncentruje się na działaniach fiskalnych stabilizujących dług publiczny. W badaniach tych dąży się do udzielenia odpowiedzi, czy kraje wysoko rozwinięte są w stanie zahamować wzrost długu publicznego, uruchamiając budżetowe nadwyżki. Drugi kierunek badań dotyczy redukcji długu publicznego w ramach realizacji dużych programów dostosowań fiskalnych. W pracach podkreśla się, że redukcja długu publicznego powinna być prowadzona po stronie wydatków (redukcji zatrudnienia w sektorze publicznym, redukcji transferów i wynagrodzeń rządowych), a nie wzrostu dochodów [Bohn 1998, Afonso, Nickel i Rother 2006, Greiner, Koeller i Semmler 2007].

Ważnym problemem badawczym dotyczącym długu publicznego jest ustalenie górnej granicy zadłużenia krajów, po której przekroczeniu wzrasta zagrożenie ich niewypłacalności. Zdaniem C.M. Reinhart, K.S. Rogoffa i M.A. Savastano [2003] za bezpieczny poziom zadłużenia kraju należy uznać poziom 30-35\% PKB. Po jego przekroczeniu ryzyko ogłoszenia niewypłacalności gwałtownie wzrasta. Według Międzynarodowego Funduszu Walutowego [International Monetary Fund and International Development Association 2004] w krajach rozwijających się górna granica długu publicznego do PKB nie powinna przekraczać 25\%, a w krajach rozwiniętych $80 \%$. Z kolei Bank Światowy [World Bank 2006] w krajach o niskim poziomie dochodu na mieszkańca ustalił wartość progową długu publicznego do PKB na poziomie $40 \%$. 
S. Hauptmeier, M. Heipertz i L. Schuknecht [2007] wykazali, że wzrost długu publicznego w relacji do PKB był w krajach UE w latach 1985-1995 spowodowany głównie wzrostem rządowych wydatków publicznych. Według Ch. Nickel, P. Rothera i L. Zimmermanna [2010] głównym powodem wzrostu długu publicznego w krajach Unii Europejskiej w czasie ostatniego kryzysu finansowego była pomoc finansowa rządów dla instytucji finansowych. Najważniejszymi czynnikami redukcji długu publicznego było obniżenie świadczeń socjalnych i wynagrodzeń w sektorze publicznym.

F. Giavazzi, T. Jappelli i M. Pagano [2000], wykorzystując modele logitowe i probitowe, udowodnili, że w krajach OECD w latach 1985-2000 konsolidacja fiskalna obniżyła poziom długu publicznego. Duże zaostrzenie polityki fiskalnej doprowadziło do redukcji długu publicznego. Zdaniem W.H. Buitera [2005] jednorazowy wzrost długu publicznego nie stanowi zagrożenia dla zrównoważonego rozwoju. Jeśli jednak uczestnicy rynku uznają, że wzrost długu ma charakter strukturalny, wówczas istnieje duże zagrożenie utratą stabilności finansowej państwa i osłabienie rozwoju sfery realnej. M. Kumar i J. Woo [2010] oraz L. Reinhart i K.S. Rogoff [2010] uważają, że wysoki poziom długu publicznego może bezpośrednio lub pośrednio spowolnić lub zahamować wzrost gospodarczy, głównie przez wyparcie inwestycji prywatnych.

A. Alesina i G. Tabellini [1990] wyjaśniają, że dług publiczny jest instrumentem zdobywania i utrzymywania władzy przez polityków. Jest on wypadkową polityki fiskalnej rządów, które sprawowały władzę. Według badaczy partie rządzące maksymalizują wartość użyteczności dla członków swojego elektoratu poprzez określoną ofertę dóbr publicznych. Im większa jest polaryzacja polityczna między partiami, tym większą tendencję mają rządy do generowania nadmiernego długu. T. Persson i L.E.O. Svensson [1989] na przykładzie USA i Wielkiej Brytanii twierdzą, że partie preferujące mniejsze wydatki publiczne w pierwszym okresie rządzenia je zwiększają, finansując je długiem, zaś w drugim okresie je zmniejszają. W przypadku partii preferujących wysokie wydatki publiczne jest odwrotnie - w pierwszym okresie rządzenia zmniejszają wydatki publiczne, a w drugim okresie je zwiększają.

Podsumowując problematykę długu publicznego poruszaną w literaturze, należy stwierdzić, że dotyczy ona przede wszystkim:

- determinant niewypłacalności państw na świecie,

- bezpiecznych progów relacji długu publicznego do PKB, po których przekroczeniu państwa mają problemy z obsługą długu publicznego,

- sposobów redukcji długu publicznego,

- wpływu długu publicznego na wzrost i rozwój gospodarczy,

- strategii polityki fiskalnej partii politycznych zamierzających je wdrożyć po przejęciu władzy. 


\section{Poziom i determinanty długu publicznego}

$\mathrm{Z}$ danych OECD wynika, że najwyższy dług publiczny na świecie w relacji do PKB w 2012 r. odnotowano w Japonii - 218,8\%, Grecji - 167,3\%, we Włoszech - 142,2\%, Portugalii - 134,5\% i Islandii - 127,5\%. Polska w rankingu najbardziej zadłużonych państw na świecie zajęła 26. miejsce z wynikiem 55,6\% PKB.

Rządowy i samorządowy dług publiczny w relacji do PKB wzrósł w Unii Europejskiej z poziomu $62 \%$ w 2000 r. do $85 \%$ w 2012 r. (rys. 1). Najwyższa dynamika wzrostu długu występowała w latach 2008-2010. W wartościach bezwzględnych dług ten wzrósł z poziomu 5,6 bln euro do 11 bln euro.

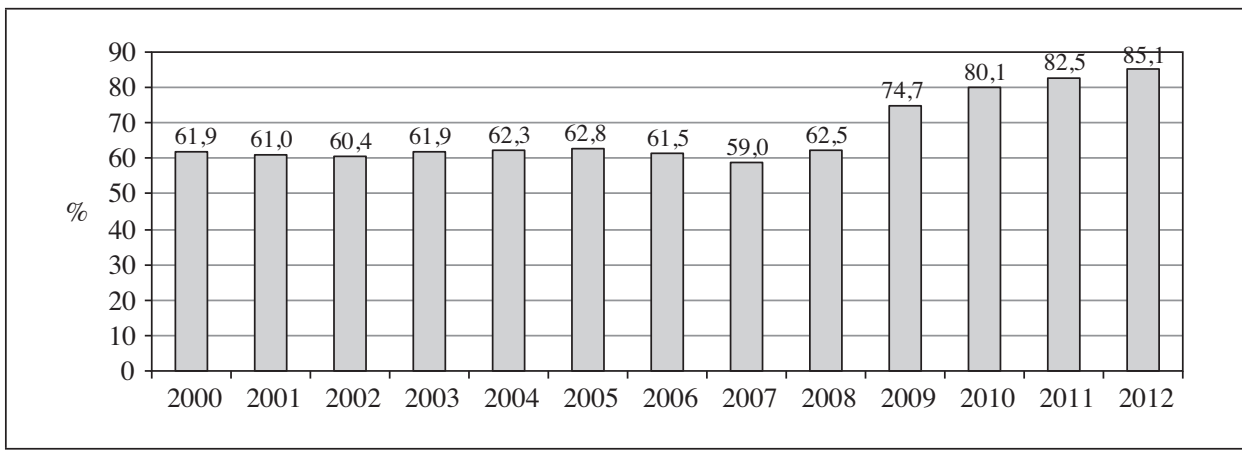

Rys. 1. Rządowy i samorządowy dług publiczny w relacji do PKB w Unii Europejskiej w latach 2000-2012

Źródło: opracowanie własne na podstawie Eurostat Data.

Spośród wszystkich krajów UE najwyższy rządowy dług publiczny w relacji do PKB w 2012 r. wystąpił w Grecji, we Włoszech i w Portugalii, a najniższy w Estonii, Bułgarii, Luksemburgu i Rumunii (rys. 2).

Dług publiczny przelicza się również na osobę. W 2012 r. rządowy dług publiczny per capita był najwyższy w Irlandii, Belgii, we Włoszech i Francji (rys. 3). Najniższy dług w przeliczeniu na osobę wystąpił w Bułgarii, Estonii i Rumunii. W Polsce wynosił on 5,6 tys. euro na osobę.

Ważnym problemem państw są koszty obsługi długu publicznego. W 2012 r. wartość odsetek od długu publicznego w odniesieniu do PKB była najwyższa we Włoszech, w Grecji i na Węgrzech, a najniższa w Estonii, Luksemburgu i Szwecji (rys. 4). W Polsce koszty obsługi długu publicznego wynosiły 2,8\% PKB. Największymi dłużnikami w Unii Europejskiej są tzw. kraje PIIGS. Głównymi ich wierzycielami są banki komercyjne z Niemiec, Francji i Wielkiej Brytanii. 
Największym dłużnikiem Niemiec jest Hiszpania (178 mld USD), Francji Włochy (410 mld USD), a Wielkiej Brytanii - Irlandia (137 mld USD).

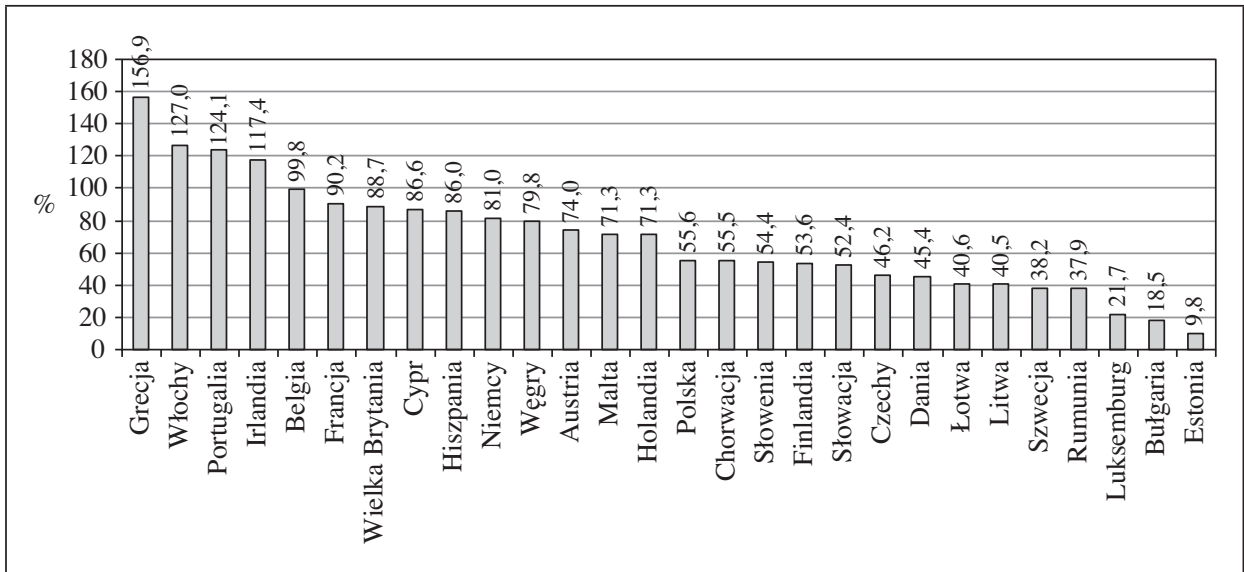

Rys. 2. Rządowy dług publiczny w relacji do PKB w krajach Unii Europejskiej w 2012 r. Źródło: opracowanie własne na podstawie Eurostat Data.

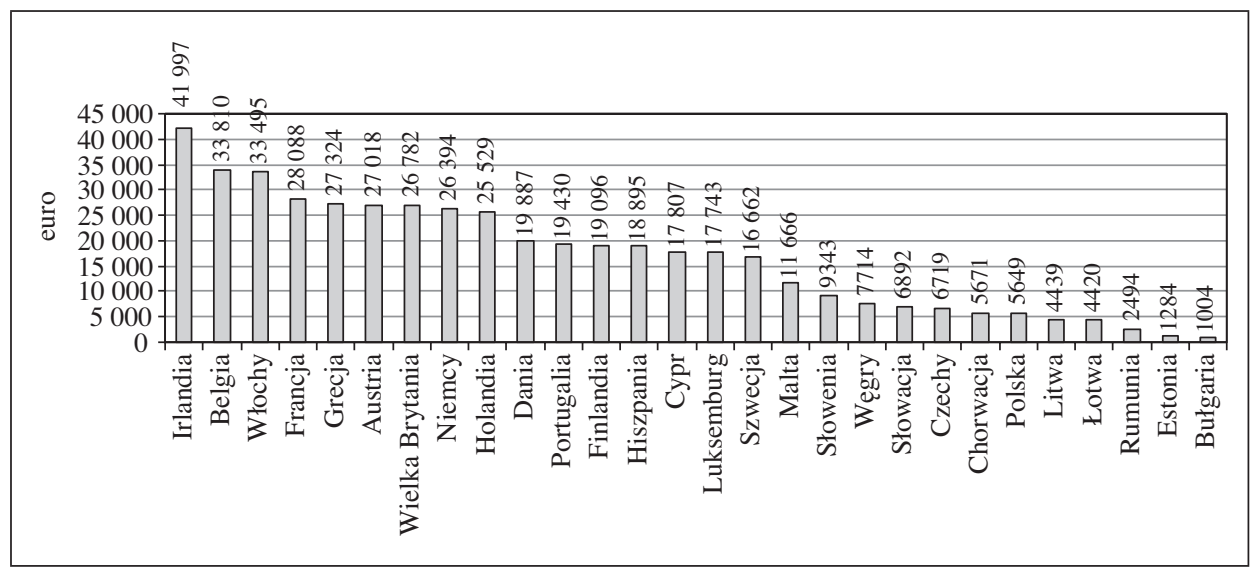

Rys. 3. Rządowy dług publiczny per capita w krajach Unii Europejskiej w 2012 r. Źródło: opracowanie własne na podstawie Eurostat Data.

W Polsce rządowy i samorządowy dług publiczny w relacji do PKB wzrósł z poziomu 36,8\% w 2000 r. do 55,6\% w 2012 r. Wynika z tego, że sytuacja finansowa państwa w ostatniej dekadzie uległa pogorszeniu. Dług publiczny w odniesieniu do PKB w ciągu 10 lat uległ podwyższeniu o prawie 20\%. Pod względem 
wartościowym wzrósł on z poziomu 273 mld zł w 2000 r. do poziomu $868 \mathrm{mld}$ zł w 2012 r. $^{3}$

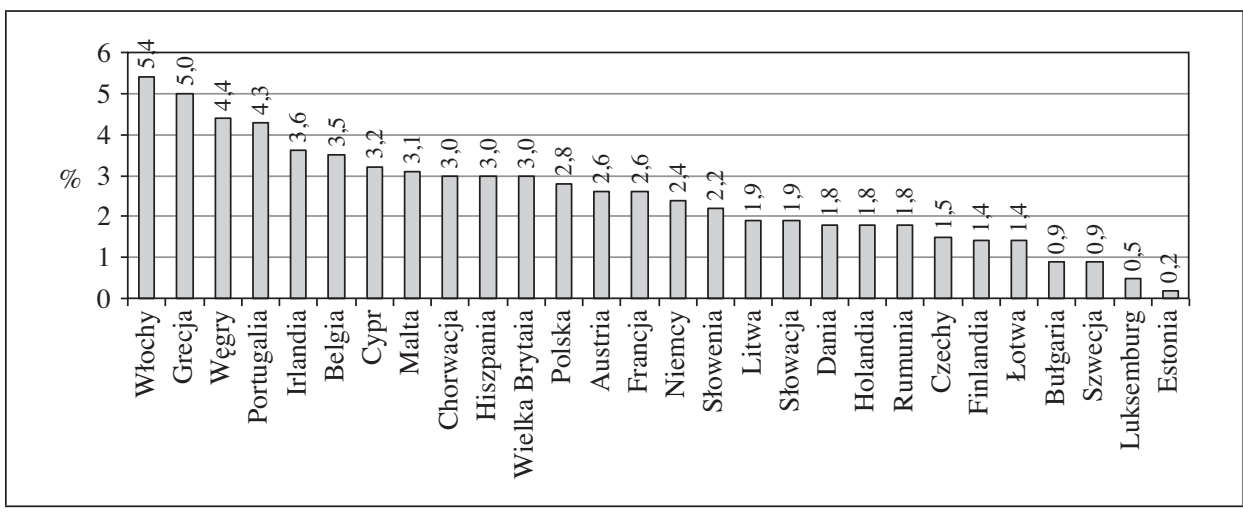

Rys. 4. Koszty obsługi długu publicznego jako procent PKB w krajach UE w 2012 r. Źródło: opracowanie własne na podstawie Eurostat Data.

W latach 2002-2012 najwyższy udział w strukturze długu publicznego w Polsce miały zobowiązania o terminie wymagalności od 1 roku do 5 lat oraz od 7 do 10 lat. W sumie stanowiły one od $53 \%$ w 2002 r. do $70 \%$ w 2012 r. Wysoki udział zobowiązań o terminie wymagalności od 1 do 5 lat w 2012 r. będzie determinował wysokie obciążenia państwa w najbliższym okresie. Głównymi wierzycielami Polski są instytucje finansowe działające na terenie naszego kraju i wierzyciele zagraniczni. W sumie w strukturze długu publicznego Polski stanowili oni od 89\% w 2002 r. do 95\% w 2012 r. Niewielkie znaczenie w strukturze długu publicznego mają przedsiębiorstwa niefinansowe i gospodarstwa domowe. Dług publiczny w Polsce był zaciągany głównie w walucie krajowej. W latach 2006-2012 stanowił on od 72\% do 75\% długu ogółem. Spośród walut obcych najwyższe kwoty zobowiązań Polska zaciągnęła w walucie euro. Dług publiczny w tej walucie stanowił od 18\% w 2006 r. do 19,8\% w 2012 r. Pozostałe waluty obce miały marginalne znaczenie w strukturze długu publicznego Polski. Koszty obsługi długu publicznego w Polsce wynosiły od 22 mld zł w 2000 r. do 45 mld zł w 2012 r. Z danych wynika, że koszty te wykazywały trend wzrostowy. Największa dynamika ich zmian wystąpiła w 2008 r.

$\mathrm{Z}$ badań własnych wynika, że na poziom rządowego długu publicznego w Polsce statystycznie istotny wpływ mają takie zmienne objaśniające, jak: napływ bezpośrednich inwestycji zagranicznych netto, wzrost eksportu towarów

${ }^{3} \mathrm{Z}$ danych Ministerstwa Finansów wynika, że dług publiczny na koniec trzeciego kwartału 2013 r. wynosił 952 mld zł. 
i usług oraz PKB per capita (tabela 1). Pierwsza i trzecia zmienna objaśniająca były dodatnio skorelowane z długiem publicznym, druga zaś ujemnie.

Tabela 1. Determinanty rządowego długu publicznego w Polsce - zmienna zależna y: centralny rządowy dług publiczny brutto (mln euro)

\begin{tabular}{|l|c|c|c|c|}
\hline \multicolumn{1}{|c|}{ Parametr regresji } & $\begin{array}{c}\text { Wartość } \\
\text { estymowana }\end{array}$ & $\begin{array}{c}\text { Błąd } \\
\text { standardowy }\end{array}$ & $\begin{array}{c}\text { Statystyka } \\
t \text {-Studenta }\end{array}$ & Wartość $p$ \\
\hline Wartość stała & $-95952,40$ & 13619,80 & $-7,05$ & $0,0004^{* *}$ \\
\hline $\begin{array}{l}\text { Napływ bezpośrednich inwestycji } \\
\text { zagranicznych netto }\left(x_{1}, \% \text { PKB) }\right.\end{array}$ & 4085,74 & 1332,48 & 3,07 & $0,0220^{*}$ \\
\hline $\begin{array}{l}\text { Wzrost eksportu towarów } \\
\text { i usług }\left(x_{2}, \%\right)\end{array}$ & $-911,34$ & 275,31 & $-3,31$ & $0,0162^{*}$ \\
\hline $\begin{array}{l}\text { PKB per capita }\left(x_{3}, \text { ceny stałe }\right. \\
\text { w USD z 2000 r.) }\end{array}$ & 37,44 & 2,65 & 14,15 & $0,0000^{* *}$ \\
\hline
\end{tabular}

Uwaga: $R^{2}=98,76 \%$; statystyka Durbina-Watsona $=1,6892$; statystycznie istotny współczynnik regresji dla zmiennych objaśniających przy $p \leq 0,05\left(^{*}\right)$ i przy $p \leq 0,01(* *)$.

Źródło: opracowanie własne na podstawie World Bank Data.

Wyznaczony model regresji: $y=4085,74 x_{1}-911,34 x_{2}+37,44 x_{3}-95$ 952,4.

Rządowy dług publiczny w Grecji zależał od wartości PKB, wydatków krajowych brutto i wydatków na wojsko (tabela 2). Pierwsza i trzecia zmienna objaśniająca były statystycznie istotnie dodatnio powiązane z długiem publicznym, a druga zmienna objaśniająca - statystycznie istotnie ujemnie.

Tabela 2. Determinanty rządowego długu publicznego w Grecji - zmienna zależna $y$ : centralny rządowy dług publiczny brutto (\% PKB)

\begin{tabular}{|l|c|c|c|c|}
\hline \multicolumn{1}{|c|}{ Parametr regresji } & $\begin{array}{c}\text { Wartość } \\
\text { estymowana }\end{array}$ & $\begin{array}{c}\text { Błąd } \\
\text { standardowy }\end{array}$ & $\begin{array}{c}\text { Statystyka } \\
t \text {-Studenta }\end{array}$ & Wartość $p$ \\
\hline Wartość stała & 327,36 & 81,63 & 4,01 & $0,0070^{* *}$ \\
\hline PKB $\left(x_{1}\right.$, mld USD) & 0,03 & 0,02 & 1,99 & $0,0443^{*}$ \\
\hline $\begin{array}{l}\text { Wydatki krajowe brutto } \\
\left(x_{2}, \% \text { PKB }\right)\end{array}$ & $-2,15$ & 0,76 & $-2,83$ & $0,0299^{*}$ \\
\hline $\begin{array}{l}\text { Wydatki na wojsko } \\
\left(x_{3}, \% \text { PKB }\right)\end{array}$ & 11,82 & 4,50 & 2,63 & $0,0391^{*}$ \\
\hline
\end{tabular}

Uwaga: $R^{2}=68,92 \%$; statystyka Durbina-Watsona = 1,5222; oznaczenia jak pod tabelą 1 . Źródło: opracowanie własne na podstawie World Bank Data.

Wyznaczony model regresji: $y=0,03 x_{1}-2,15 x_{2}+11,82 x_{3}+327,36$. 
Determinantami rządowego długu publicznego w USA były takie zmienne objaśniające, jak: napływ bezpośrednich inwestycji zagranicznych netto, eksport towarów i usług oraz wzrost podaży pieniądza (tabela 3). Pierwsza zmienna objaśniająca była skorelowana statystycznie ujemnie z rządowym długiem publicznym, a druga i trzecia statystycznie dodatnio.

Tabela 3. Determinanty rządowego długu publicznego w USA - zmienna zależna $y$ : centralny rządowy dług publiczny brutto (mln euro)

\begin{tabular}{|l|c|c|c|c|}
\hline \multicolumn{1}{|c|}{ Parametr regresji } & $\begin{array}{c}\text { Wartość } \\
\text { estymowana }\end{array}$ & $\begin{array}{c}\text { Błąd } \\
\text { standardowy }\end{array}$ & $\begin{array}{c}\text { Statystyka } \\
t \text {-Studenta }\end{array}$ & Wartość $p$ \\
\hline Wartość stała & -6388970 & 748801 & $-8,53$ & $0,0135^{*}$ \\
\hline $\begin{array}{l}\text { Napływ bezpośrednich inwestycji } \\
\text { zagranicznych netto }\left(x_{1}, \% \text { PKB) }\right.\end{array}$ & -847727 & 191600 & $-4,42$ & $0,0475^{*}$ \\
\hline $\begin{array}{l}\text { Eksport towarów } \\
\text { i usług }\left(x_{2}, \text { mld USD) }\right.\end{array}$ & 13,05 & 0,90 & 14,47 & $0,0047^{* *}$ \\
\hline Wzrost podaży pieniądza $\left(x_{3}, \%\right)$ & $320437 \cdot 10^{6}$ & $6,91 \cdot 10^{10}$ & $-4,64$ & $0,0435^{*}$ \\
\hline
\end{tabular}

Uwaga: $R^{2}=99,30 \%$; statystyka Durbina-Watsona = 1,4389; oznaczenia jak pod tabelą 1 .

Źródło: opracowanie własne na podstawie World Bank Data.

Wyznaczony model regresji: $y=-847727 x_{1}+13,05 x_{2}+320437 \cdot 10^{6} x_{3}-$ +6388970.

Podsumowując trzy przedstawione modele regresji, należy stwierdzić, że we wszystkich modelach wartości statystyki Durbina-Watsona były wyższe niż 1,4, co oznacza, że nie było prawdopodobnie ${ }^{4}$ istotnych korelacji między resztami (błędami obserwacji). Poza tym współczynniki determinacji $R^{2} \mathrm{w}$ opracowanych modelach były wysokie, co oznacza, że modele te dobrze odzwierciedlały dane empiryczne.

$\mathrm{Z}$ analizy literatury przedmiotu wynika, że czynnikami decydującymi o zdolności państwa do spłaty długu publicznego są: wartość zobowiązań, stopień rozwoju gospodarczego kraju, skuteczność polityki stabilizacyjnej państwa, podatność gospodarki na wstrząsy, skala zasilania gospodarki przez przepływy pieniężne z zagranicy, struktura walutowa i terminowa długu [Alesina i Tabellini 1990, Jeanne i Guscina 2006, Reinhart, Rogoff i Savastano 2003, Reinhart i Rogoff 2008, 2009, s. 25; 2010, 2011a, 2011b].

Skutkami nadmiernego długu publicznego mogą być: obciążenie przyszłych pokoleń kosztami spłaty zadłużenia, obniżenie poziomu życia społeczeństwa w przyszłości, wysoka inflacja, spadek ratingów wiarygodności finansowej

${ }^{4}$ Użyto słowa „prawdopodobnie”, gdyż test Durbina-Watsona wykrywa autokorelacje reszt pierwszego rzędu, a nie wykrywa autokorelacji reszt wyższego rzędu. 
państw, kryzysy finansowe oraz niebezpieczeństwo niewypłacalności państw [Diamond 1965, Owsiak 2005, Battaglini i Coate 2008, Reinhart i Rogoff 2011a].

\section{Dług publiczny jako instrument stymulowania i hamowania wzrostu gospodarczego}

Z badań C. Checherity i P. Rothera [2010] w 12 krajach strefy euro będących członkami UE w latach 1970-2010 wynika nieliniowy związek między wzrostem gospodarczym a wartością długu publicznego. Wzrost długu publicznego w PKB do poziomu $70-80 \%$ stymuluje wzrost gospodarczy, po czym jego wyższy poziom hamuje wzrost gospodarczy. Istnieją również dowody, że związek między wzrostem gospodarczym mierzonym PKB per capita a rocznymi zmianami długu publicznego i deficytem w relacji do PKB jest ujemny i liniowy. Kanałami, za których pośrednictwem dług publiczny (poziom i zmiany) ma wpływ na tempo wzrostu gospodarczego, są: prywatne oszczędności, inwestycje publiczne, produktywność czynników produkcji oraz długoterminowe nominalne i realne stopy procentowe.

Tabela 4. Związek między wzrostem gospodarczym a długiem publicznym w wybranych krajach na świecie w latach 1995-2012

\begin{tabular}{|l|c|c|c|c|c|c|}
\hline \multirow{2}{*}{ Kraj } & \multicolumn{2}{|c|}{$\begin{array}{c}\text { Dług publiczny } \\
\text { (\% PKB) }\end{array}$} & \multicolumn{2}{c|}{$\begin{array}{c}\text { Roczna zmiana długu } \\
\text { publicznego } \% \text { PKB) }\end{array}$} & \multicolumn{2}{c|}{$\begin{array}{c}\text { Koszty obsługi długu } \\
\text { publicznego (\% PKB) }\end{array}$} \\
\cline { 2 - 7 } & $r$ & $b$ & $r$ & $b$ & $r$ & $b$ \\
\hline Austria & $-0,36$ & $-0,177$ & $-0,01$ & $-0,0001$ & 0,31 & 1,160 \\
\hline Belgia & 0,20 & 0,024 & 0,30 & 0,043 & 0,35 & 0,303 \\
\hline Bułgaria & $-0,05$ & $-0,006$ & $-0,22$ & $-0,002$ & 0,29 & 0,705 \\
\hline Chorwacja & $\cdot$ & $\cdot$ & $-0,27$ & $-0,036$ & 0,61 & 3,816 \\
\hline Cypr & $-0,51^{* *}$ & $-0,136^{* *}$ & $0,80^{* * *}$ & $0,038^{* * *}$ & 0,17 & 0,841 \\
\hline Czechy & $-0,21$ & $-0,062$ & $-0,10$ & $-0,032$ & $-0,46^{*}$ & $-8,461^{*}$ \\
\hline Dania & 0,36 & 0,062 & $0,44^{*}$ & $0,055^{*}$ & 0,26 & 0,831 \\
\hline Estonia & $-0,23$ & $-0,990$ & $-0,24$ & $-0,002$ & 0,05 & 3,086 \\
\hline Finlandia & 0,12 & 0,062 & 0,10 & 0,055 & $0,45^{*}$ & $1,453^{*}$ \\
\hline Francja & $-0,48^{* *}$ & $-0,071^{* *}$ & $-0,49^{* *}$ & $-0,075^{* *}$ & 0,34 & 1,530 \\
\hline Grecja & $-0,94^{* * *}$ & $-0,165^{* * *}$ & 0,14 & 0,004 & $-0,23$ & $-1,133$ \\
\hline Hiszpania & $-0,30$ & $-0,055$ & $-0,29$ & $-0,057$ & 0,29 & 0,573 \\
\hline Holandia & $-0,02$ & $-0,004$ & $-0,08$ & $-0,021$ & 0,58 & 0,987 \\
\hline Irlandia & $-0,57^{* *}$ & $-0,062^{* *}$ & $-0,47$ & $-0,063$ & $-0,49$ & $-1,891$ \\
\hline Litwa & $-0,33$ & $-0,213$ & 0,37 & 0,547 & $-0,25$ & $-3,005$ \\
\hline
\end{tabular}


cd. tabeli 4

\begin{tabular}{|l|c|c|c|c|c|c|}
\hline \multirow{2}{*}{ Kraj } & \multicolumn{2}{|c|}{$\begin{array}{c}\text { Dług publiczny } \\
\text { (\% PKB) }\end{array}$} & \multicolumn{2}{c|}{$\begin{array}{c}\text { Roczna zmiana długu } \\
\text { publicznego }\end{array}$} & \multicolumn{2}{c|}{$\begin{array}{c}\text { Koszty obsługi długu } \\
\text { publicznego (\% PKB) }\end{array}$} \\
\cline { 2 - 7 } & $r$ & $b$ & $r$ & $b$ & $r$ & $b$ \\
\hline Luksemburg & $-0,58^{* *}$ & $-0,375^{* *}$ & $-0,02$ & $-0,016$ & $-0,38$ & $-13,163$ \\
\hline Łotwa & $-0,51^{* *}$ & $-0,293^{* *}$ & $-0,19$ & $-0,001$ & $-0,52^{* *}$ & $-9,731^{* *}$ \\
\hline Malta & $-0,62^{* * *}$ & $-0,156^{* * *}$ & 0,15 & 0,012 & $-0,24$ & $-1,409$ \\
\hline Niemcy & 0,00 & $-0,0005$ & $0,43^{*}$ & $0,308^{*}$ & 0,03 & 0,168 \\
\hline Polska & $-0,06$ & $-0,020$ & $-0,31$ & $-0,018$ & $-0,53^{*}$ & $-3,785^{*}$ \\
\hline Portugalia & $-0,73^{* * *}$ & $-0,088^{* * *}$ & 0,34 & 0,122 & 0,15 & 0,456 \\
\hline Rumunia & $-0,23$ & $-0,132$ & 0,32 & 0,059 & $-0,56^{* *}$ & $-2,006^{* *}$ \\
\hline Słowacja & $-0,51^{* *}$ & $-0,201^{* *}$ & 0,24 & 0,072 & $-0,22$ & $-0,801$ \\
\hline Słowenia & $-0,64^{* * *}$ & $-0,235^{* * *}$ & $0,50^{* *}$ & $0,173^{* *}$ & 0,11 & 0,911 \\
\hline Szwecja & 0,22 & 0,045 & 0,34 & 0,027 & 0,23 & 0,368 \\
\hline Wielka Brytania & $-0,54^{* *}$ & $-0,076^{* *}$ & $-0,53^{* *}$ & $-0,071^{* *}$ & 0,29 & 1,031 \\
\hline Węgry & $-0,69^{* * *}$ & $-0,188^{* * *}$ & $0,47^{*}$ & $0,038^{*}$ & 0,01 & 0,023 \\
\hline Włochy & $-0,23$ & $-0,066$ & $-0,17$ & $-0,065$ & 0,34 & 0,318 \\
\hline Norwegia & $-0,04$ & $-0,006$ & 0,51 & 0,078 & $\cdot$ & $\cdot$ \\
\hline Rosja & 0,09 & 0,027 & $-0,18$ & $-0,500$ & $\cdot$ & $\cdot$ \\
\hline Szwajcaria & $-0,04$ & $-0,027$ & $-0,33$ & $-0,134$ & $\cdot$ & $\cdot$ \\
\hline Kanada & 0,31 & 0,045 & $-0,41$ & $-0,210$ & $\cdot$ & $\cdot$ \\
\hline USA & $-0,24$ & $-0,031$ & $-0,56$ & $-0,277$ & $\cdot$ & $\cdot$ \\
\hline Chiny & $-0,93^{* *}$ & $-0,619^{* *}$ & $-0,87$ & $-1,093$ & $-0,38$ & $-3,213$ \\
\hline Indie & $-0,24$ & $-0,031$ & 0,42 & 0,298 & $-0,41^{*}$ & $-3,037^{*}$ \\
\hline Japonia & $-0,93^{* *}$ & $-0,619^{* *}$ & $-0,32$ & $-0,079$ & $\cdot$ & $\cdot$ \\
\hline Australia & 0,00 & 0,002 & $-0,17$ & $-0,041$ & $\cdot$ & $\cdot$ \\
\hline Brazylia & $-0,17$ & $-0,030$ & 0,70 & 0,552 & $-0,39$ & $-0,966$ \\
\hline & & & & & $\cdot$ \\
\hline
\end{tabular}

Uwaga: współczynnik korelacji Pearsona $r$ i współczynnik regresji $b$ statystycznie istotny przy: $p \leq 0,01(* * *), p \leq 0,05(* *)$ i $p \leq 0,1(*)$.

Źródło: opracowanie własne na podstawie danych Eurostat Data i World Bank Data.

F. Modigliani [1961] twierdzi, że dług publiczny jest korzystny dla obecnego pokolenia, ale jest dużym obciążeniem dla przyszłych pokoleń. Uznaje on dług publiczny za pozytywny, w przypadku gdy jest on źródłem wydatków na inwestycje, które w przyszłości mogą przyczynić się do generowania realnych dochodów ludności. P. Diamond [1965] dowodzi, że poprzez wpływy podatków skierowanych na pokrycie kosztów obsługi długu spada konsumpcja i oszczędności ludności. 
C.S. Adam i D.L. Bevan [2005] stwierdzają w modelu teoretycznym, że wzrost wydatków rządowych przeznaczonych na produkcję sfinansowanych dochodami z podwyższenia stawek podatkowych stymuluje wzrost gospodarczy, pod warunkiem że krajowy dług publiczny jest na niskim poziomie. J. Aizenman, K. Kletzer i B. Pinto [2007], analizując w modelach endogenicznych wzrostu wpływ polityki fiskalnej, stwierdza, że wzrost poziomu długu publicznego wpływa negatywnie na wzrost gospodarczy.

P. Krugman [1988] uważa, że zagraniczny dług publiczny tylko do pewnego poziomu może wspierać rozwój inwestycji, a tym samym wzrost gospodarczy. Przekroczenie tego poziomu będzie wywoływało silną negatywną presję na inwestorach zagranicznych, zniechęcającą do udzielania następnych pożyczek. D.A. Aschauer [2000] w modelu wzrostu wykazał nieliniowy związek między wzrostem gospodarczym a poziomem zadłużenia państwa. Według autora dług publiczny do pewnego progu ma wpływ pozytywny na wzrost gospodarczy, zaś po jego przekroczeniu już tylko wpływ negatywny.

C. Pattillo, H. Poirson i L. Ricci [2002] stwierdzili w 93 krajach rozwiniętych w latach 1969-1998 negatywny wpływ długu publicznego przekraczającego poziom 35-40\% PKB na wzrost gospodarczy. Podobne wyniki uzyskali B. Clements, R. Bhattacharya i T.Q. Nguyen [2003] w 55 krajach o niskim PKB w latach 1970-1999.

Inne wcześniejsze badania empiryczne [Smyth i Hsing 1995, Cohen 1997] potwierdzają nieliniowy związek wzrostu gospodarczego i długu zagranicznego. Z kolei A. Schclarek [2004] wykazał liniowy negatywny wpływ zewnętrznego zadłużenia na poziom wzrostu PKB per capita w 59 rozwiniętych krajach w latach 1970-2002. W innych badaniach na próbie 24 krajów przemysłowych w latach 1970-2002 nie stwierdził związku między rządowym długiem brutto a wzrostem gospodarczym PKB per capita.

Z kolei C. Reinhart i K.S. Rogoff [2010] wykazali w 20 krajach rozwiniętych w latach 1790-2009 słaby dodatni związek między długoterminowym wzrostem gospodarczym a rządowym długiem publicznym nieprzekraczającym progu $90 \%$ PKB i ujemny związek po jego przekroczeniu. Podobne relacje wzrostu gospodarczego w stosunku do długu publicznego odnotowano w pracy [Kumar i Woo 2010].

Z badań własnych przeprowadzonych w latach 1995-2012 wynika, że wzrost długu publicznego powoduje spadek wzrostu gospodarczego w większości badanych krajów na świecie (tabela 4). Podobną zależność zaobserwowano między wzrostem gospodarczym a roczną zmianą długu publicznego. W przypadku związku kosztów długu publicznego ze wzrostem gospodarczym sytuacja jest niejednoznaczna. W niektórych badanych krajach koszty długu publicznego są skorelowane ze wzrostem gospodarczym dodatnio, w innych zaś ujemnie. 
Z perspektywy polityki fiskalnej przedstawione wyniki dostarczają dodatkowych argumentów, żeby redukować wysoki dług publiczny i dzięki temu wspierać długoterminowy wzrost gospodarczy. Przegląd literatury wskazuje, że do sposobów przeciwdziałania wzrostowi długu publicznego możemy zaliczyć: przeprowadzenie reform gospodarczych, zachowanie dyscypliny budżetowej państwa, wzrost podatków i (lub) obniżanie wydatków państwa, zmniejszenie biurokracji, zmniejszenie szarej strefy, wzrost dochodów z prywatyzacji, wzrost środków finansowych na badania naukowe i rozwój, stymulowanie przyrostu demograficznego poprzez aktywną politykę prorodzinną rządu oraz wprowadzenie odpowiedzialności karnej za skutki złego rządzenia państwem, w tym zadłużenie kraju [Eichengreen 1991, Reinhart i Rogoff 2010].

\section{Podsumowanie}

W historii długu publicznego na świecie najwyższy jego poziom wystąpił na przełomie XIX i XX w., w czasie wielkiego kryzysu gospodarczego, po II wojnie światowej, w ostatniej dekadzie XX w. oraz obecnie po wybuchu ostatniego kryzysu finansowego.

Z danych Eurostatu i Banku Światowego, a także badań własnych wynikają następujące wnioski:

1. Najwyższy dług publiczny w relacji do PKB na świecie w 2012 r. wystąpił w Japonii (208\%), w Grecji (167\%), we Włoszech (142\%) i w Portugalii (134\%). W Unii Europejskiej średnio wynosi on 85\%, a w Polsce 55,6\%. W większości krajów na świecie, w tym w USA i w krajach Unii Europejskiej, dług publiczny w ostatniej dekadzie wykazuje trend wzrostowy.

2. Istotnym czynnikiem wzrostu długu publicznego był światowy kryzys finansowy w latach 2008-2010, który wymusił w wielu krajach rządową pomoc finansową dla banków, czego efektem było pogorszenie stanu finansów publicznych.

3. Wprowadzenie Paktu fiskalnego przez UE może w dłuższym okresie poprawić wypłacalność krajów, natomiast obecnie nie istnieje koncepcja, jak wyjść z kryzysu finansów publicznych. Widoczne jest tylko pewne pozorowanie działań w tym zakresie przez liderów krajów UE, natomiast brak konkretów.

4. Ogromne zadłużenie niektórych krajów UE będzie wymagało umorzenia części długów i restrukturyzacji pozostałych. Kraje takie jak Grecja, Portugalia czy Włochy nie są w stanie spłacić tak wielkich zobowiązań. Prawdopodobne straty dotkną wierzycieli zarówno sektora publicznego, jak i prywatnego.

5. Zadłużenie państw Unii Europejskiej jest efektem działań polityków, którzy poprzez wzrost wydatków utrzymują lub podwyższają poziom życia społe- 
czeństwa, co nie ma pokrycia we wzroście gospodarczym. Chodzi o to, aby jak najdłużej zachowywać władzę i płynące z tego korzyści.

6. Z badań własnych wynika, że wzrost długu publicznego w większości badanych krajów na świecie powoduje spadek wzrostu gospodarczego. Wynika z tego, że założona hipoteza badawcza została potwierdzona.

7. Najbardziej niekorzystny wpływ na wzrost gospodarczy krajów ma zagraniczny dług publiczny, którego spłata wraz z odsetkami wymusza transfer środków finansowych do wierzycieli zagranicznych, co obniża popyt globalny, a tym samym wartość produktu krajowego brutto.

8. Dług publiczny uznaje się za pozytywny, jeśli jest on źródłem wydatków na inwestycje, które w przyszłości mogą przyczynić się do generowania realnych dochodów ludności. Wpływ długu publicznego na gospodarkę najbardziej negatywny jest wówczas, gdy finansuje się nim biurokrację. Wzrost podatków skierowanych na spłatę długu i pokrycie kosztów jego obsługi powoduje spadek konsumpcji i oszczędności ludności.

9. Skutkami wysokiego długu publicznego są duże obciążenia przyszłych pokoleń kosztami spłaty zadłużenia, obniżenie stopy życiowej społeczeństwa, obniżenie wiarygodności finansowej krajów, jak również możliwość wystąpienia kryzysów finansowych i groźba niewypłacalności państw.

\section{Literatura}

Adam C.S., Bevan D.L. [2005], Fiscal Deficits and Growth in Developing Countries, ,Journal of Public Economics”, vol. 89(4), http://dx.doi.org/10.1016/ j.jpubeco.2004.02.006.

Afonso A., Nickel C., Rother P. [2006], Fiscal Consolidations in the Central and Eastern European Countries, „Review of World Economics”, vol. 142(2), http://dx.doi. org/10.1007/s10290-006-0073-9.

Aizenman J., Kletzer K., Pinto B. [2007], Economic Growth with Constraints on Tax Revenues and Public Debt: Implications for Fiscal Policy and Cross-country Differences, NBER Working Paper, No 07-01.

Alesina A., Tabellini G. [1990], A Positive Theory of Fiscal Deficits and Government Debt, ,The Review of Economic Studies”, vol. 57(3), http://dx.doi.org/10.2307/2298021.

Aschauer D.A. [2000], Do States Optimize? Public Capital and Economic Growth, „The Annals of Regional Science", vol. 34(3), http://dx.doi.org/10.1007/s001689900016.

Barro R. [1979], On the Determination of the Public Debt, „,Journal of Political Economy”, vol. 87(5), http://dx.doi.org/10.1086/260807.

Battaglini M., Coate S. [2008], A Dynamic Theory of Public Spending, Taxation, and Debt, „American Economic Review”, vol. 98(1), http://dx.doi.org/10.1257/aer.98.1.201.

Bohn H. [1998], The Behavior of U.S. Public Debt and Deficits, ,Quarterly Journal of Economics", vol. 113(3), http://dx.doi.org/10.1162/003355398555793.

Buiter W.H. [2005], Joys and Pains of Public Debt, Springer, Dordrecht. 
Checherita C., Rother P. [2010], The Impact of High and Growing Government Debt on Economic Growth - an Empirical Investigation for the Euro Area, ECB Working Paper, No. 1237.

Clements B., Bhattacharya R., Nguyen T.Q. [2003], External Debt, Public Investment, and Growth in Low-income Countries, IMF Working Paper, No. 03/249.

Cohen D. [1997], Growth and External Debt: a New Perspective on the African and Latin American Tragedies, Centre for Economic Policy Research Discussion Paper, No. 1753.

Diamond P. [1965], National Debt in a Neoclassical Growth Model, „American Economic Review", vol. 55(5).

Dobosz M. [2001], Wspomagana komputerowo statystyczna analiza wyników badań, Akademicka Oficyna Wydawnicza Exit, Warszawa.

Eichengreen B. [1991], Historical Research on International Lending and Debt, ,Journal of Economic Perspectives", vol. 5(2), http://dx.doi.org/10.1257/jep.5.2.149.

Giavazzi F., Jappelli T., Pagano M. [2000], Searching for Non-linear Effects of Fiscal Policy: Evidence from Industrial and Developing Countries, ,European Economic Review", vol. 44(7).

Greiner, A., Koeller W., Semmler W. [2007], Debt Sustainability in the European Monetary Union: Theory and Empirical Evidence for Selected Countries, „Oxford Economic Papers", vol. 59(2), http://dx.doi.org/10.1093/oep/gpl035.

Hauptmeier S., Heipertz M., Schuknecht L. [2007], Expenditure Reform in Industrialised Countries - A Case Study Approach, „Fiscal Studies”, vol. 28(3).

International Monetary Fund and International Development Association [2004], Debt Sustainability in Low-Income Countries - Proposal for an Operational Framework and Policy Implications, Washington.

Jeanne O., Guscina A. [2006], Government Debt in Emerging Market Countries: A New Data Set, IMF Working Paper, No. 06/98.

Krugman P. [1988], Financing vs. Forgiving a Debt Overhang, ,Journal of Development Economics", vol. 29(3).

Kumar M., Woo J. [2010], Public Debt and Growth, IMF Working Paper, No. 10/174.

Modigliani F. [1961], Long-run Implications of Alternative Fiscal Policies and the Burden of the National Debt, ,Economic Journal”, vol. 71(284).

Nickel Ch., Rother P., Zimmermann L. [2010], Major Public Debt Reductions - Lessons from the Past, Lessons for the Future, European Central Bank, Working Paper No 1241.

Owsiak S. [2005], Finanse publiczne. Teoria i praktyka, PWN, Warszawa.

Pattillo C., Poirson H., Ricci L. [2002], External Debt and Growth, IMF Working Paper, No. 02/69.

Persson T., Svensson L.E.O. [1989], Why a Stubborn Conservative Would Run a Deficit: Policy with Time-inconsistent Preferences, „Quarterly Journal of Economics”, vol. 104(2), http://dx.doi.org/10.2307/2937850.

Reinhart C.M., Rogoff K.S. [2008], This Time Is Different: A Panoramic View of Eight Centuries of Financial Crises, NBER Working Paper, No. 13882.

Reinhart C.M., Rogoff K.S. [2009], This Time is Different: Eight Centuries of Financial Folly, Princeton University Press, Princeton.

Reinhart C.M., Rogoff K.S. [2010], Growth in a Time of Debt, „American Economic Review", vol. 100(2). 
Reinhart C.M., Rogoff K.S. [2011a], The Forgotten History of Domestic Debt, „Economic Journal", vol. 121(552).

Reinhart C.M., Rogoff K.S. [2011b], From Financial Crash to Debt Crisis, „American Economic Review”, vol. 101(5), http://dx.doi.org/10.1257/aer.101.5.1676.

Reinhart C.M., Rogoff K.S., Savastano M.A. [2003], Debt Intolerance, „Brookings Papers on Economic Activity", Spring.

Roubini N., Sachs J. [1989], Political and Economic Determinants of Budget Deficits in the Industrial Democracies, „European Economic Review”, vol. 33(5).

Schclarek A. [2004], Debt and Economic Growth in Developing Industrial Countries, Department of Economics, Lund University, Lund, Sweden, mimeo.

Smyth D., Hsing Y. [1995], In Search of an Optimal Debt Ratio for Economic Growth, „Contemporary Economic Policy”, vol. 13(4), http://dx.doi.org/10.1111/ j.1465-7287.1995.tb00731.x.

World Bank [2006], How to Do a Debt Sustainability Analysis for Low-Income Countries, Washington.

\section{Public Debt as a Threat to Growth in Selected World Economies}

The main aim of this work is to determine the relationship between the level of economic growth and the level of public debt in selected countries around the world. An additional aim of the study is to establish the level and determinants of public debt in these countries. The data obtained show that an increase in public debt causes a decrease in economic growth in most countries around the world.

Keywords: public debt, determinants of public debt, economic growth, costs of servicing public debt. 